\title{
Inhibitory effects of a luteinizing-hormone-releasing hormone agonist implant on ovine fetal gonadotrophin secretion and pituitary sensitivity to luteinizing-hormone- releasing hormone
}

\author{
A. N. Brooks and A. S. McNeilly \\ MRC Reproductive Biology Unit, Centre for Reproductive Biology, 37 Chalmers Street, \\ Edinburgh EH3 $9 E W, U K$
}

\begin{abstract}
Summary. Sheep fetuses at day 70 of gestation (term $=145$ days) were implanted subcutaneously with a biodegradable implant containing a luteinizing-hormonereleasing hormone (LHRH) agonist (buserelin) to investigate whether treatment with LHRH agonist would induce a state of desensitization of the fetal gonadotrophs and thus influence fetal gonadal development.

Treatment with the LHRH agonist for 35-40 days caused a significant reduction in mean fetal plasma concentrations of $\mathrm{LH}$ and follicle-stimulating hormone (FSH) compared with control fetuses. LH pulses were evident in control fetuses but were completely abolished by buserelin treatment. Furthermore, the pituitary content of LH and FSH was significantly depleted in fetuses implanted with LHRH agonist. A bolus intravenous injection of $500 \mathrm{ng}$ LHRH given to control fetuses caused a rapid and significant increase in plasma LH and FSH concentrations which was sustained for at least $60 \mathrm{~min}$ after injection. Pretreatment with buserelin completely abolished the LH and FSH responses to a bolus injection of LHRH. There were no differences between the sexes in fetal gonadotrophin concentrations or pituitary sensitivity to LHRH in control or agonist-treated fetuses. Furthermore, buserelin treatment for 35-40 days had no effect on the morphological appearance of the fetal gonads when compared with control fetuses, at least to day 110 of pregnancy.

These results provide evidence for the induction of a state of densensitization of the LHRH receptors of the fetal pituitary gonadotrophs following long-term treatment with an LHRH agonist, but provide no evidence for a role for gonadotrophin secretion in gonadal development at this stage in fetal life.
\end{abstract}

Keywords: fetus; sheep; gonadotrophin; LHRH; agonist

\section{Introduction}

Concentrations of luteinizing hormone ( $\mathrm{LH})$ and follicle-stimulating hormone (FSH) in plasma of fetuses follow a characteristic pattern of change throughout pregnancy in many species. Concentrations of LH and FSH in plasma of sheep and human fetuses are higher at mid-gestation than before birth (Foster et al., 1972; Sklar et al., 1981; Mulchahey et al., 1987). Furthermore, there is a difference between the sexes in fetal gonadotrophins; concentrations of circulating LH and FSH are lower in male than in female fetuses (Kaplan et al., 1976; Sklar et al., 1981). This difference has been attributed to the negative feedback effects of high circulating testosterone concentrations seen in male fetuses (Ellinwood et al., 1982; Matwijiw \& Faiman, 1989). LH is secreted in a pulsatile fashion in sheep fetuses (Clark et al., 1984; Matwijiw \& Faiman, 1989), pig fetuses (Ponzilius et al., 
1986) and rhesus monkey fetuses (Jaffe et al., 1988). This pulsatile mode of LH secretion depends on luteinizing-hormone-releasing hormone (LHRH) since administration of an LHRH receptor antagonist to immature sheep fetuses blocks episodic LH secretion (Matwijiw \& Faiman, 1987).

A physiological role for these high fetal gonadotrophin concentrations has been implied, largely on the basis of data obtained from anencephalic human fetuses. In this situation, male fetuses usually have hypoplastic male external genitalia, undescended testes and a reduced number of Leydig cells (Kaplan et al., 1976). In the female fetus the stage of intense transformation of oogonia into primordial follicles coincides with high concentrations of FSH in the fetus (Grumbach \& Kaplan, 1973). The female anencephalic fetus has small hypoplastic ovaries and reduced numbers of primordial and primary follicles (Ross, 1974; Kaplan et al., 1976). Hypophysectomy of rhesus monkey fetuses decreases the weight of the fetal testis as well as the percentage of Leydig cells and spermatogonia. In female fetuses hypophysectomy decreases ovarian weight and causes an increase in germ cell atresia (Gulyas et al., 1977a, b). These data therefore support the concept that in monkeys and humans the fetal pituitary is intimately involved in the regulation of gonadal maturation. However, they do not distinguish between gonadotrophin and other pituitary secretions in the regulation of these events.

This study evaluated the ability of an LHRH agonist, buserelin, to induce a state of desensitization of the fetal gonadotrophs to elucidate the functional role of fetal gonadotrophins. We investigated whether continuous administration of buserelin to immature sheep fetuses reduces circulating $\mathrm{LH}$ and FSH concentrations and inhibits pulsatile LH secretion, and as a consequence influences morphological development of the fetal gonads.

\section{Materials and Methods}

\section{Animals and surgery}

Twenty pregnant Scottish Blackface ewes with known single insemination dates were used. On day 70 of gestation

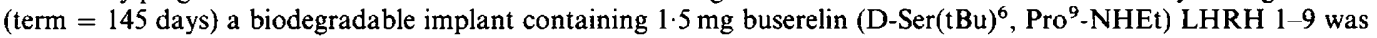
placed subcutaneously into the axillary region of the fetal hind leg. General anaesthesia was induced with alphaxalone $(0.9 \%)$ plus alphadalone $(0.3 \%)\left(0.5 \mathrm{mg} \mathrm{kg}^{-1}\right.$ i.v.; Saffan: Glaxovet, Uxbridge, Middlesex, UK) and maintained with $2-3 \%$ halothane (May and Baker, Dagenham, Essex, UK) in oxygen at a flow rate of $0.41 \mathrm{~min}^{-1}$. A midline lower abdominal incision allowed exposure of the fetus through a small uterine incision. The implant was introduced subcutaneously and secured by a single 6-0 suture. Antibiotics were administered into the amniotic fluid before closure ( $10^{6}$ units penicillin; Grystapen: Glaxovet) and to the ewe (Streptopen: Glaxovet) for 3 days after surgery. In twin pregnancies both fetuses were implanted and control fetuses did not receive an implant.

On day 100 of gestation polyvinyl catheters were placed in the fetal carotid artery and jugular vein using the methods of Brooks \& White (1981). Antibiotics were given to the fetus and ewe for 3 days after surgery and at least 5 days elapsed before experiments began.

\section{Experimental protocol}

On day 106 of gestation blood samples $(0.8 \mathrm{ml})$ were withdrawn from the carotid artery of the fetus at $15 \mathrm{~min}$ intervals for between 4 and $6 \mathrm{~h}$. At the end of this sampling period $500 \mathrm{ng}$ LHRH (Hoechst, Frankfurt, Germany) dissolved in $2 \mathrm{ml}$ sterile saline was rapidly injected into the fetal jugular vein and a further three arterial blood samples were collected 15, 30 and $60 \mathrm{~min}$ later. Samples were collected into chilled polypropylene tubes, centrifuged within $30 \mathrm{~min}$ at $1500 \mathrm{~g}$ for $10 \mathrm{~min}$ at $4^{\circ} \mathrm{C}$, and plasma was stored at $-15^{\circ} \mathrm{C}$ until assayed. This protocol was repeated at day 110 of gestation. At day 111 the sheep were killed with an overdose of sodium pentobarbitone and the whole fetal pituitary glands quickly removed and weighed before being snap frozen in liquid nitrogen prior to storage at $-70^{\circ} \mathrm{C}$. Fetal gonads were weighed, cut into two and placed immediately in 0.2 mol collidine $1^{-1}$ containing $4 \%$ gluteraldehyde, $0.05 \% \mathrm{CaCl}_{2}$ and $0.1 \mathrm{~mol}$ sucrose $\mathrm{l}^{-1}$. Tissue blocks were processed to fixation in Epon-Araldite and $1 \mu \mathrm{m}$ sections were cut and stained with Toluidine Blue.

\section{Pituitary extraction}

Frozen fetal pituitaries (including the anterior, posterior and intermediate lobes) were homogenized using a glass homogenizer in $1 \mathrm{ml} 50 \mathrm{mmol} \mathrm{Na}{ }_{2} \mathrm{CO}_{3} 1^{-1}$ containing $1 \%$ Triton $\mathrm{X}-100(\mathrm{pH} \mathrm{7.4)}$. After 30 min incubation at room 
temperature, a $20 \mu \mathrm{l}$ aliquot was removed for protein determination using a BioRad assay kit. The remaining homogenate was centrifuged at $10000 \mathrm{~g}$ for $30 \mathrm{~min}$ and the supernatant was stored at $-15^{\circ} \mathrm{C}$ until assayed.

\section{Radioimmunoassays}

Concentrations of $\mathrm{LH}$ were measured in $50 \mu \mathrm{l}$ aliquots of plasma and diluted pituitary extracts by radioimmunoassay using the method of McNeilly et al. (1986). The lower limit of detection was improved by halving the quantities of reagents added to each tube and within this study was $0.05 \mathrm{ng} \mathrm{ml}^{-1}$ using NIH-LH-S23 as a reference standard. The mean inter- and intra-assay coefficients of variation were $12.5 \%$ and $8 \%$, respectively, for three quality control plasma pools included in each assay. Concentrations of FSH were also measured using a similar modified version of the radioimmunoassay method of McNeilly et al. (1976). The lower limit of sensitivity was $0.4 \mathrm{ng} \mathrm{ml}^{-1}$ using anti-oFSHl and RPI standard and the inter- and intra-assay coefficients of variation were $11 \%$ and $9 \%$, respectively.

\section{Statistical analysis}

The influence of buserelin and sex of the fetus on pituitary and plasma gonadotrophin concentrations was assessed by two-way analysis of variance. Duncan's multiple range test was used to test for significant differences between individual means. Student's $t$-test was used to compare the characteristics of LH secretion between male and female control fetuses. Pulses of LH were defined as occurring when the concentration of LH measured in one plasma sample was greater than the mean of the concentrations of the previous two samples by at least twice the coefficient of variation of the assay. Pulse amplitude was the peak concentration of LH for each pulse and the mean LH concentration was the average of all $\mathrm{LH}$ concentrations during a sampling window. In all cases statistical significance was set at $P<0.05$.

\section{Results}

\section{Influence of buserelin on LH and FSH secretion, pituitary responsiveness to LHRH and pituitary gonadotrophin content}

LH secretion was pulsatile in all male and female control fetuses (Fig. 1). Owing to the short duration of sampling on any one occasion, an estimate of the interpulse interval was made by dividing the total number of hours during which samples were taken by the number of pulses detected. This estimate of interpulse interval did not differ between male and female fetuses $(5 \cdot 2$ versus $6.0 \mathrm{~h}$, Table 1). There were no significant differences in LH pulse amplitude or average LH concentrations between male and female control fetuses (Table 1).

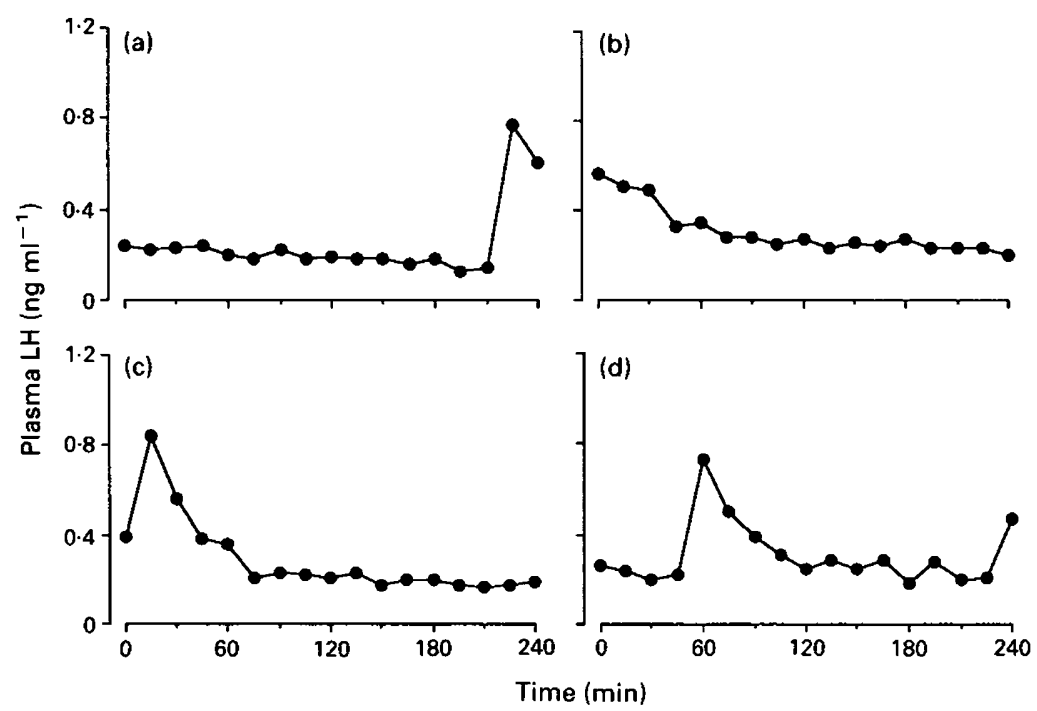

Fig. 1. Representative luteinizing hormone ( $\mathbf{L H})$ profiles in control male $(\mathrm{a}, \mathrm{c})$ and female $(\mathrm{b}, \mathrm{d})$ catheterized sheep fetuses at $106(\mathrm{a}, \mathrm{b})$ and $110(\mathrm{c}, \mathrm{d})$ days gestation (term $=145$ day). Blood samples were withdrawn at 15 min intervals for $4 \mathrm{~h}$. 
Table 1. Characteristics of luteinizing hormone ( $\mathrm{LH})$ secretion in male and female control fetuses

\begin{tabular}{|c|c|c|}
\hline Characteristics & Male & Female \\
\hline Number of fetuses & 4 & 6 \\
\hline Total observation time $(\mathrm{h})$ & 26 & 42 \\
\hline Total number of LH pulses & 5 & 7 \\
\hline Average interpulse interval $(h)^{\mathrm{ab}}$ & $5 \cdot 2$ & $6 \cdot 0$ \\
\hline LH pulse amplitude $\left(\mathrm{ng} \mathrm{ml}^{-1}\right)^{\mathrm{b}}$ & $1.03 \pm 0.27$ & $0.85 \pm 0.15$ \\
\hline Average $L H$ concentration $\left(\mathrm{ng} \mathrm{ml^{-1 }}\right)^{b}$ & $0.41 \pm 0.09$ & $0.26 \pm 0.02$ \\
\hline
\end{tabular}

LH secretion was non-pulsatile and mean plasma concentrations of LH and FSH were significantly reduced $(P<0.05)$ in agonist-treated fetuses compared with controls. The sex of the fetus did not influence this response (Table 2). Intravenous injection of a bolus of LHRH (500 ng) induced a significant increase in plasma LH and FSH concentrations in all control fetuses and this response was completely abolished (as assessed by comparing peak $\mathrm{LH}$ and FSH concentrations after LHRH) following 4 weeks of treatment with LHRH agonist (Fig. 2; Table $1 ; P<0 \cdot 01$ ). Pituitary LH and FSH concentrations were dramatically reduced in agonist implanted fetuses compared with controls $(P<0.001)$ and this effect was independent of the sex of the fetus (Table 3).

Table 2. Influence of buserelin on luteinizing hormone ( $\mathrm{LH})$ and follicle-stimulating hormone (FSH) secretion

\begin{tabular}{lcccc}
\hline & \multicolumn{2}{c}{ Male } & \multicolumn{2}{c}{ Female } \\
& $\begin{array}{c}\text { Control } \\
(n=4)\end{array}$ & $\begin{array}{c}\text { Buserelin } \\
(n=5)\end{array}$ & $\begin{array}{c}\text { Control } \\
(n=6)\end{array}$ & $\begin{array}{c}\text { Buserelin } \\
(n=5)\end{array}$ \\
\hline Average LH $\left(\mathrm{ng} \mathrm{ml}^{-1}\right)$ & $0.41 \pm 0.09$ & $0.24 \pm 0.06^{*}$ & $0.26 \pm 0.02$ & $0.14 \pm 0.02^{*}$ \\
Average FSH $\left(\mathrm{ng} \mathrm{ml}^{-1}\right)$ & $1.71 \pm 0.39$ & $0.56 \pm 0.16^{*}$ & $1.68 \pm 0.15$ & $1.09 \pm 0.17^{*}$ \\
\hline
\end{tabular}

*Significantly $(P<0.05)$ different from controls.

\section{Influence of buserelin on gonadal development}

There were no significant differences in the weights of the fetal pituitaries, ovaries or testes (calculated as a percentage of body weight) between control and buserelin-treated fetuses (data not shown). On histological examination, the testes of control and agonist-treated fetuses appeared morphologically similar (Fig. 3). Seminiferous tubules were similar in size and contained many spermatogonia occupying a predominantly basal orientation. The interstitial spaces were large and contained numerous Leydig cells. The number of Leydig cells and their degree of differentiation were unchanged by agonist treatment. The fetal ovaries were characterized by a cortical layer of primordial follicles of varying diameter. The number, size and distribution of this follicular layer was not influenced by agonist treatment (Fig. 3).

\section{Discussion}

In this study we have demonstrated that continuous administration of an LHRH agonist, buserelin, to sheep fetuses between 70 and 110 days of gestation results in desensitization of the fetal pituitary gonadotrophs. This is characterized by a reduction in circulating LH and FSH 

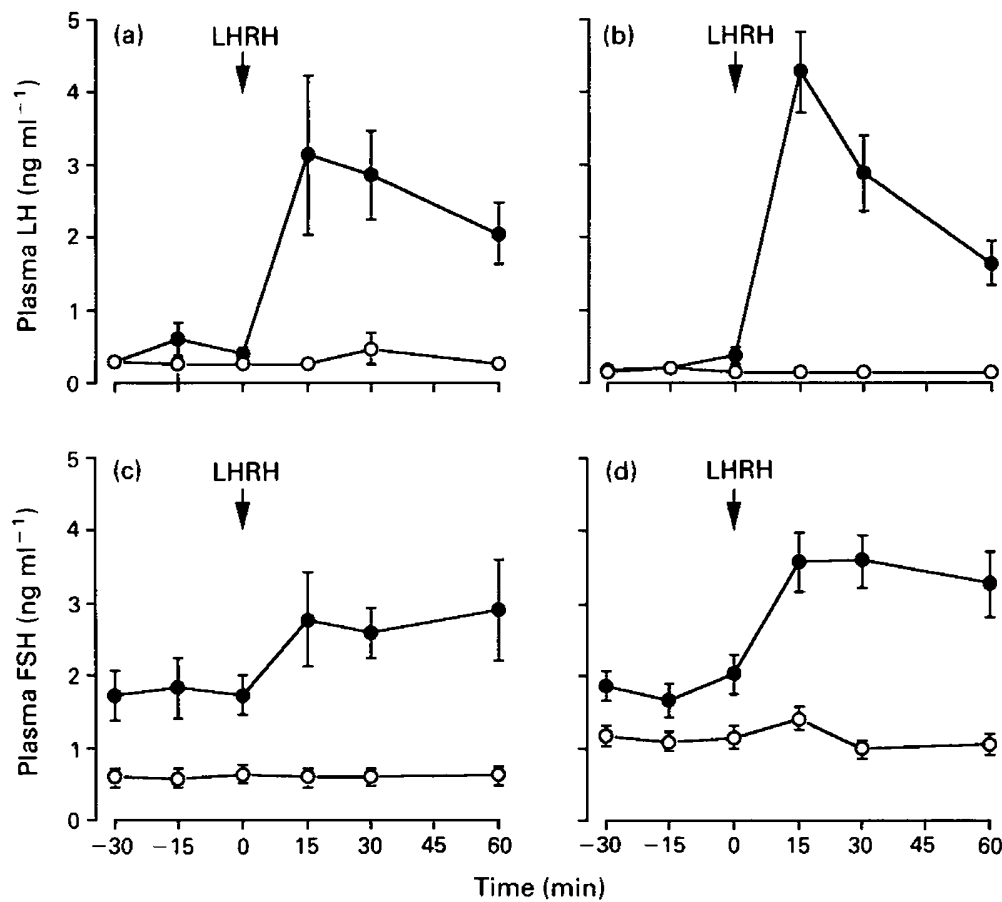

Fig. 2. Changes in the concentration (mean \pm SEM) of luteinizing hormone (LH) and folliclestimulating hormone (FSH) in control $(O)$ and buserelin implanted $(O)$ male $(a, c)$ and female (b, d) fetuses studied at 110 days gestation during an i.v. injection of $500 \mathrm{ng}$ luteinizinghormone-releasing hormone (LHRH).

Table 3. Influence of buserelin on pituitary luteinizing hormone (LH) and folliclestimulating hormone (FSH) concentrations

\begin{tabular}{|c|c|c|c|c|}
\hline & \multicolumn{2}{|c|}{ Male } & \multicolumn{2}{|c|}{ Female } \\
\hline & $\begin{array}{l}\text { Control } \\
(n=4)\end{array}$ & $\begin{array}{c}\text { Buserelin } \\
(n=5)\end{array}$ & $\begin{array}{l}\text { Control } \\
(n=6)\end{array}$ & $\begin{array}{c}\text { Buserelin } \\
(n=5)\end{array}$ \\
\hline $\mathrm{LH}$ (ng mg ${ }^{-1}$ protein) & $650 \cdot 9 \pm 20 \cdot 1$ & $48 \cdot 7 \pm 11 \cdot 1^{*}$ & $654 \cdot 7 \pm 199$ & $74.2 \pm 5.9^{*}$ \\
\hline FSH (ng mg ${ }^{-1}$ protein) & $328 \cdot 2 \pm 47 \cdot 1$ & $13.55 \pm 3.39^{*}$ & $372 \cdot 3 \pm 34 \cdot 4$ & $18.49 \pm 4.08^{*}$ \\
\hline
\end{tabular}

*Significantly $(P<0 \cdot 001)$ different from controls.

concentrations, an absence of LH pulses, a marked reduction in pituitary gonadotrophin content and the lack of a gonadotrophin response to an LHRH challenge. Despite this reduction in the functional capacity of the fetal pituitary gonadotrophs, there were no effects on the morphological development of the fetal gonads.

The effects of buserelin on fetal plasma LH and FSH concentrations are in agreement with previous studies in adults. For instance Lincoln et al. (1986) showed that continuous infusion of buserelin to adult Soay rams inhibited LH and FSH secretion and abolished LH pulses. Likewise, McNeilly \& Fraser (1987) found that buserelin inhibited LH and FSH in adult ewes. In both reports the induction of a state of desensitization by continuous LHRH agonist treatment was preceded by a period of hyperstimulation resulting in high circulating gonadotrophin concentrations. It is not possible to say whether this also occurred in the present study. However, a recent 

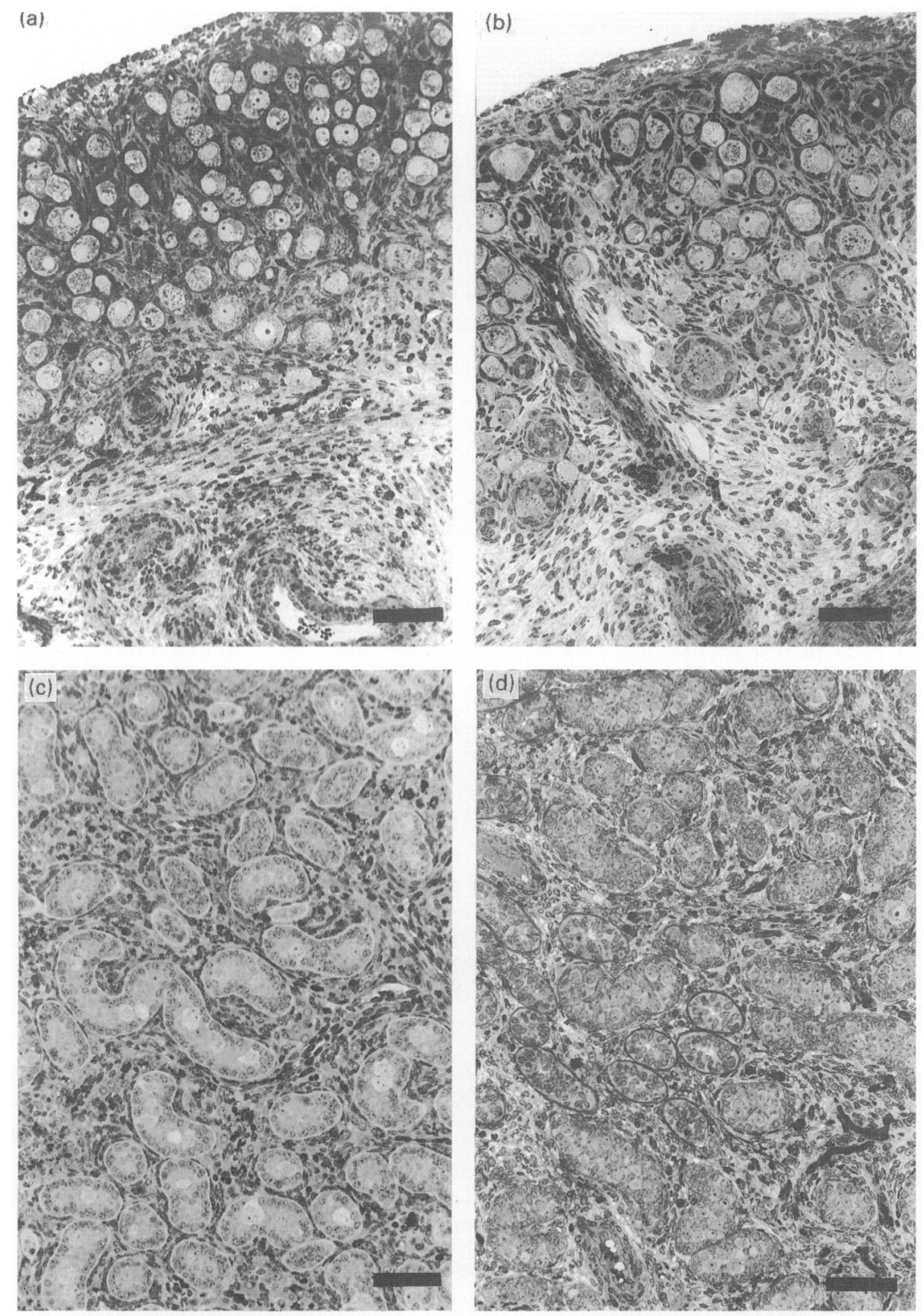

Fig. 3. Representative photomicrographs of fetal gonads from (a) control female, (b) agonist implanted female, (c) control male and (d) agonist implanted male fetuses. Buserelin implants were inserted at day 70 and tissues collected at day 111 of gestation. The solid bars represent $50 \mu \mathrm{m}$.

report shows that daily administration of an LHRH agonist to sheep fetuses beginning on day 106 of gestation causes an initial stimulatory response before the pituitary gonadotrophs are suppressed (Clark et al., 1989). A stimulatory response would have occurred in the present study only if the fetal pituitary at day 70 contains intact $\mathrm{LH}$ and FSH and possesses functional GnRH receptors. LH has been detected in the sheep fetal pituitary by immunofluorescent techniques (Dubois \& 
Mauleon, 1969) and electron microscopy (Alexander et al., 1973) by about day 50 of gestation. However, there are no data available concerning the ontogeny of GnRH receptors and their functional coupling to intracellular second messengers, in sheep.

The reduced pituitary content of LH and FSH to between 5 and $10 \%$ of control values implies that buserelin inhibits fetal gonadotrophin synthesis as well as secretion. In adult sheep, treatment with buserelin for 6 weeks is associated with reduced LH- $\beta$ mRNA levels and a reduction in LH content similar to that observed in the fetus (McNeilly et al., 1991). In contrast, pituitary FSH content was reduced to only $30 \%$ of control values. The difference between this and the drastic reduction in FSH content in the fetal pituitary implies that there is a maturation of GnRH regulatory mechanisms governing gonadotrophin synthesis and storage such that there is a decline in GnRH regulation of FSH from fetal to adult life.

In control fetuses, there were no significant differences in average plasma LH or FSH concentrations, LH pulse frequency or LH pulse amplitude, between male and female fetuses. This is in agreement with other studies in sheep fetuses which show no differences in average LH interpulse interval or pulse amplitude between male and female fetuses at an equivalent stage in gestation to the present study (Matwijiw \& Faiman, 1989). However, at mid-gestation (i.e. about day 70) fetal LH and FSH concentrations are higher in female than in male fetuses (Sklar et al., 1981), a difference that is thought to result from high testosterone concentrations in male fetuses (Matwijiw \& Faiman, 1989). Clearly this sex difference is not maintained throughout pregnancy, probably as a result of increasing circulating steroids of placental origin that have the potential to exert negative feedback effects on the hypothalamo-pituitary-gonadal axis (Gluckman et al., 1983).

The finding that suppression of fetal gonadotrophin secretion between day 70 and day 111 of gestation had no effect on the morphological development of the fetal gonads was surprising in view of data showing that removal of the fetal pituitary results in abnormal development of the fetal gonads (Liggins \& Kennedy, 1968; VanVorstenbosch, 1984). There are a number of explanations for this. Buserelin is likely to reduce LH and FSH secretion specifically without affecting other pituitary secretions. Thus trophic factors other than the fetal gonadotrophins may be important in the regulation of the developing gonads. Alternatively, the fetal gonadotrophins may regulate gonadal development at a later stage in gestation. The effects of hypophysectomy or anencephaly on gonadal development have all been examined in fetuses after normal or caesarean delivery (Liggins \& Kennedy, 1968; Ross, 1974; Gulyas et al., 1977a, b). Clearly, if fetal gonadotrophins do influence gonadal development it will be important to determine whether there is a critical stage in fetal development when they exert their actions. Another possible explanation is that, whereas LH and FSH are significantly reduced by buserelin, there are still measurable basal concentrations in the fetal circulation which may be sufficient to maintain normal gonadal development. At present the relative roles of $\mathrm{LH}$ and $\mathrm{FSH}$ and the duration or level of exposure necessary for gonadal maturation are unknown.

In conclusion, we have shown that long term administration of an LHRH agonist to sheep fetuses between day 70 and day 110 of gestation results in desensitization of the fetal pituitary gonadotrophs and a decline in circulating gonadotrophin concentrations. However, at this gestational age there were no effects on the development of the fetal gonads. These data illustrate the functional nature of the hypothalamo-pituitary-gonadal axis during fetal life in sheep and demonstrate the usefulness of GnRH agonist treatment for in vivo studies of hypothalamo-pituitary actions during fetal development.

We thank N. Anderson, B. Graham and F. Gibson for their expert technical assistance, M. Millar for help with the histology, T. McFeters and T. Pinner for artwork, R. Humke (Hoechst) for the generous supply of buserelin implants and the NIDDK and the National Hormone and Pituitary Program (University of Maryland School of Medicine, USA) for some of the radioimmunoassay reagents. 


\section{References}

Alexander, D.P., Britton, H.G., Cameron, E. \& Foster, C.L. (1973) Adenohypophysis of foetal sheep: correlation of ultrastructure with functional activity. Journal of Physiology 230, 10P-12P.

Brooks, A.N. \& White, A. (1990) Activation of pituitaryadrenal function in fetal sheep by corticotrophinreleasing factor and arginine vasopressin. Journal of Endocrinology 124, 27-35.

Clark, S.J., Ellis, N., Styne, D.M., Gluckman, P.D., Kaplan, S.L. \& Grumbach, M.M. (1984) Hormone ontogeny in the ovine fetus. XVII. Demonstration of pulsatile luteinizing hormone secretion by the fetal pituitary gland. Endocrinology 115, 1774-1779.

Clark, S.J., Hauffa, B.P., Rodens, K.P., Styne, D.L., Kaplan, S.L. \& Grumbach, M.M. (1989) Hormone ontogeny in ovine fetus: XIX: The effect of a potent luteinizing hormone-releasing factor agonist on gonadotropin and testosterone release in the fetus and neonate. Pediatric Research 25, 347-352.

Dubois, M. \& Mauleon, P. (1969) Mise en évidence par immunofluorescence des cellules à activitié gonadotrope LH dans l'hypophyse du foetus de brebis. Comptes Rendus de l'Academie des Sciences (Paris) 269, 219-222.

Ellinwood, W.E., Baughman, W.L. \& Resko, J.A. (1982) The effects of gonadectomy and testosterone treatment on luteinizing hormone secretion in fetal rhesus monkeys. Endocrinology 110, 183-189.

Foster, D.L., Roach, J.F., Karsch, F.J., Norton, H.W., Cook, B. \& Nalbandov, A.V. (1972) Regulation of luteinizing hormone in the fetal and neonatal lamb. I. LH concentrations in blood and pituitary. Endocrinology 90, 102-111.

Gluckman, P.D., Marti-Henneberg, C., Kaplan, S.L. \& Grumback, M.M. (1983) Hormone ontogeny in the ovine fetus: XIV. The effect of $17 \beta$-estradiol infusion on fetal plasma gonadotrophins and prolactin and the maturation of sex steroid-dependent negative feedback. Endocrinology 112, 1618-1623.

Grumbach, M.M. \& Kaplan, S.L. (1973) Ontogenesis of growth hormone, insulin, prolactin and gonadotropin secretion in the human fetus. In Fetal and Neonatal Physiology, pp. 462-487. Eds R. S. Comline, K. W. Cross, G. S. Dawes \& P. W. Nathanielsz. Cambridge University Press, Cambridge.

Gulyas, B.J., Hodgen, G.D., Tullner, W.W. \& Ross, G.T. (1977a) Effects of fetal or maternal hypophysectomy on endocrine organs and body weight in infant rhesus monkeys (Macaca mulatta): with particular emphasis on oogenesis. Biology of Reproduction 16, 216-227.

Gulyas, B.J., Tullner, W.W. \& Hodgen, G.D. (1977b) Fetal or maternal hypophysectomy in rhesus monkeys (Macaca mulatta): effects on the development of testes and other endocrine organs. Biology of Reproduction 17, 650-660.

Jaffe, R.B., Mulchahey, J.D., Blasio, A.M., Martin, M.C., Blumenfeld, Z. \& Dumesic, D.A. (1988) Peptide regulation of pituitary and target tissue function and growth in the primate fetus. Recent Progress in Hormone Research 44, 43I-549.

Kaplan, S.L., Grumbach, M.M. \& Aubert, M.L. (1976) The ontogenesis of pituitary hormones and hypothalamic factors in the human fetus: maturation of central nervous system regulation of anterior pituitary function. Recent Progress in Hormone Research 32, 161-243.

Liggins, G.C. \& Kennedy, P.C. (1968) Effects of electrocoagulation of the foetal lamb hypophysis on growth and development. Journal of Endocrinology 40, 371-381.

Lincoln, G.A., Fraser, H.M. \& Abbott, M.P. (1986) Blockade of pulsatile LH, FSH and testosterone secretion in rams by constant infusion of an LHRH agonist. Journal of Reproduction and Fertility 77, 587-597.

McNeilly, A.S. \& Fraser, H.M. (1987) Effect of gonadotrophin-releasing hormone agonist-induced suppression of $\mathrm{LH}$ and FSH on follicle growth and corpus luteum function in the ewe. Journal of Endocrinology 115, 273-282.

McNeilly, A.S., Jonassen, J.A. \& Fraser, H.M. (1986) Suppression of follicular development after chronic LHRH immunoneutralization in the ewe. Journal of Reproduction and Fertility 76, 481-490.

McNeilly, J.R., McNeilly, A.S., Walton, J.S. \& Cunningham, F.J. (1976) Development and application of a heterologous radioimmunoassay for ovine follicle stimulating hormone. Journal of Endocrinology 70, 69-79.

McNeilly, J.R., Brown, P., Clark, A.J. \& McNeilly, A.S. (1991) Gonadotrophin-releasing hormone modulation of gonadotrophins in the ewe: evidence for differential effects on gene expression and hormone secretion. Journal of Molecular Endocrinology 7, 35-43.

Matwijiw, I. \& Faiman, C. (1987) Control of gonadotropin secretion in the ovine fetus: the effects of a specific gonadotropin-releasing hormone antagonist on pulsatile luteinizing hormone secretion. Endocrinology 121, 347-351.

Matwijiw, I. \& Faiman, C. (1989) Control of gonadotropin secretion in the ovine fetus. II. A sex difference in pulsatile luteinizing hormone secretion after castration. Endocrinology 124, 1352-1358.

Mulchahey, J.J., DiBlasio, A.M., Martin, M.C., Blumenfeld, Z. \& Jaffe, R.B. (1987) Hormone production and peptide regulation of the human fetal pituitary gland. Endocrine Reviews 8, 406-425.

Ponzilius, K-H., Elaesser, P.F. \& Ellendorff, F. (1986) Ontogeny of secretory patterns of LH release and effects of gonadectomy in the chronically catheterized pig fetus and neonate. Biology of Reproduction 34, 602-612.

Ross, G.T. (1974) Gonadotrophins and preantral follicular maturation in women. Fertility and Sterility 25, 522-543.

Sklar, C.A., Mueller, P.L., Gluckman, P.D., Kaplan, S.L., Rudolph, A.M. \& Grumbach, M.M. (1981) Hormone ontogeny in the ovine fetus. VII. Circulating luteinizing hormone and follicle-stimulating hormone in mid- and late gestation. Endocrinology 108, 874-880.

VanVorstenbosch, C.J.A.H.V., Colenbrander, B. \& Wensing, C.J.G. (1984) Leydig cell development in the pig testis during late fetal and early post-natal period: an electron microscopic study with attention to the influence of fetal decapitation. American Journal of Anatomy 169, 121-136.

Received 18 November 1991 